\title{
PEMBELAJARAN MATEMATIKA DENGAN PENDEKATAN REALISTIC MATHEMATICS EDUCATION (RME) BERBASIS SOAL OPEN - ENDED UNTUK MENINGKATKAN KOMUNIKASI MATEMATIKA
}

\author{
Akhamd Fauzi ${ }^{1}$; Budi Waluya ${ }^{2}$; Masrukan ${ }^{3}$ \\ ${ }^{1,2,3}$ Prodi Pendidikan Dasar Matematika Program Pascasarjana Universitas Negeri \\ Semarang
}

\begin{abstract}
This study aims to determine the feasibility and effectiveness of the application of learning using social arithmetic textbooks using the Realistic Mathematics Education (RME) approach based on Open-Ended questions. The research design used in this study is Research and Development ( $R$ and $\mathrm{D})$ with the Plomp model. The subjects in this study were the eighth grade students of Askhabul Kahfi Integrated Islamic Middle School, Academic Year 2017/2018. The design implements using Posttest Only Control-Group Design. The analysis used is the analysis of the results of expert validation and effectiveness test. The results of the post test in the class that the action was carried out were compared with the class that did not take the action and to ensure it was done with (1) Completeness Test, (2) Difference Test, and (3) Simple Linear Regression Test. Based on the results of research and discussion, it was concluded that; (1) Mathematics learning tools with the developed RME approach are valid based on expert expert assessments, and according to the results of small class and large class trials, and (2) Mathematics learning tools with the developed RME approach are effective. This is indicated by (a) the average value of evaluating classroom communication skills using mathematics learning tools $73,42(\mu>70)$ and classical completeness of $76,6 \%(\pi>75 \%)$; (b) the average class that uses the application of mathematics learning tools with the RME approach based on open-ended questions $(73,42)$ bigger than a class that does not use the application of mathematics learning tools with the open-ended question based RME approach $(64,57)$, and (c) from the regression test obtained $t_{\text {hitung }}=2,012$, $t_{\text {hitung }}(2,012)>$ $t_{\text {tabel }}(1,99834)$.
\end{abstract}

Keywords: Realistic mathematics education (RME), Mathematical communication, Social arithmetic and comparison 


\begin{abstract}
Abstrak
Penelitian ini bertujuan untuk mengetahui kelayakan dan keefektifan dari penerapan pembelajaran menggunakan buku ajar aritmatika sosial menggunakan pendekatan Realistic Mathematics Education (RME) berbasis soal Open-Ended. Desain penelitian yang digunakan dalam penelitian ini adalah Research and Development ( $R$ dan $D$ ) dengan model Plomp. Subjek dalam penelitian ini adalah siswa kelas VIII SMP Islam Terpadu Askhabul Kahfi Tahun Pelajaran 2017/ 2018. Desain implentasi menggunakan Posttest Only Control-Group Design. Analisis yang digunakan berupa analisis hasil validasi ahli dan uji keefektifan. Hasil post test pada kelas yang dilakukan tindakan dibandingkan dengan kelas yang tidak dilakukan tindakan dan untuk memastikannya dilakukan dengan (1) Uji Ketuntasan, (2) Uji Beda, dan (3) Uji Regresi Linier Sederhana. Berdasarkan hasil penelitian dan pembahasan, diperoleh simpulan bahwa (1) Perangkat pembelajaran aritmetika dengan pendekatan RME yang dikembangkan valid digunakan berdasarkan dari penilaian pakar ahli, dan sesuai hasil uji coba kelas kecil dan kelas besar, dan (2) Perangkat pembelajaran aritmetika dengan pendekatan RME yang dikembangkan efektif. Hal ini ditunjukkan dengan (a) rerata nilai evaluasi kemampuan komunikasi kelas yang menggunakan perangkat pembelajaran matematika 73, $42(\mu>70)$ dan ketuntasan klasikal sebesar 76,6\% ( $\pi>75 \%$ ); (b) rerata kelas yang menggunakan penerapan perangkat pembelajaran matematika dengan pendekatan RME berbasis soal open-ended $(73,42)$ lebih besar dari kelas yang tidak menggunakan penerapan perangkat pembelajaran matematika dengan pendekatan RME berbasis soal open-ended $(64,57)$, serta (c) dari uji regresi diperoleh $\mathrm{t}_{\text {hitung }}=2,012$, $\mathrm{t}_{\text {hitung }}(2,012)>\mathrm{t}_{\text {tabel }}(1,99834)$.
\end{abstract}

Kata kunci: Realistic mathematics education (RME), Komunikasi matematika, Aritmatika sosial dan perbandingan

\title{
PENDAHULUAN
}

Masalah mendasar yang dihadapi dalam dunia pendidikan di Indonesia sekarang adalah bagaimana meningkatkan kualitas pendidikan. Kualitas pendidikan selalu dikaitkan dengan pencapaian hasil belajar yang diperoleh siswa yang diidentifikasikan dengan skor hasil tes. Selain itu juga kualitas pendidikan tidak dapat terlepas dari kualitas proses pembelajaran yang dilakukan guru.

Matematika adalah salah satu mata pelajaran yang menduduki peranan penting dalam pendidikan. Hal ini disebabkan karena matematika digunakan secara luas dalam segala bidang kehidupan manusia. Oleh karena itu pelajaran matematika dalam pelaksanaan pendidikan diberikan kepada jenjang pendidikan mulai dari Sekolah Dasar (SD) sampai dengan Perguruan Tinggi (PT). Mutu pendidikan matematika mulai tahun 1975 sampai sekarang terkesan tidak meningkat, apabila dibandingkan dengan negaranegara yang dulu keadaannya relatif sama dengan Indonesia, misal Malaysia, Singapura, Philipina, dan sebagainya (Marpaung, 2003). Sesuai dengan kenyataan 
bahwa nilai rerata Ujian Nasional matematika SMP Islam Terpadu Askhabul Kahfi masih menunjukkan hasil yang rendah.

Kenyataan di lapangan transfer pengetahuan atau proses belajar mengajar yang dilakukan guru selama ini terlalu berorientasi pada penguasaan materi pelajaran dan tidak memperhatikan makna atau nilai yang terkandung dari materi pelajaran. Khususnya pada mata pelajaran Matematika SMP Islam Terpadu Askhabul Kahfi materi bentuk aritmatika sosial. Berdasarkan observasi dan wawancara terhadap siswa SMP Islam Terpadu Askhabul Kahfi dan guru mata pelajaran Matematika, ternyata sebagian siswa masih mengalami kesulitan memahami materi aritmatika social dan pembelajaran masih terpusat pada guru.

Strategi pembelajaran yang diharapkan mampu menggeser penggunaan model pembelajaran secara cemarah serta mengaktifkan dan mengkreatifkan siswa pada suatu proses pembelajaran, terutama pada pembelajaran matematika diantaranya adalah melalui pendekatan RME (Relistic Mathematics Education) berpendekatan soal openended. Kedua pendekatan pembelajaran ini merupakan strategi baru yang sama-sama mengajak siswa untuk lebih aktif dan kreatif dalam berpikir dan mengkomunikasikan gagasan dalam menyelesaikan suatu persoalan matematika bagi siswa. Pendekatan RME dapat digunakan pada setiap jenjang pendidikan, sehingga mudah dikembangakan sesuai dengan kondisi (Dickinson, et.al., 2010).

Relistic Mathematics Education (RME) dengan soal open-ended sebagai salah satu pendekatan baru dalam pembelajan matematika, juga mengajak siswa memotivasi kontekstual yaitu kegiatan pola pikir siswa yang dikembangkan dari hal-hal yang bersifat konkrit menuju hal-hal abstrak. Pembelajaran matematika dengan model RME dengan soal open-ended pada dasarnya adalah pemanfaatan realita dan lingkungan yang dipahami siswa untuk memperlancar proses pembelajaran matematika sehingga mencapai tujuan pendidikan matematika yang lebih baik dari masa lalu (Dickinson \& Hough, 2012: 1). Realita yang dimaksud adalah hal-hal yang nyata atau konkrit yang dapat diamati dan dipahami siswa dengan membayangkan, sedangkan lingkungan adalah tempat dimana siswa berada (Soedjadi, 2000). Fauzan (2011) menyatakan bahwa RME memberikan kesempatan kepada siswa untuk bertindak secara aktif mencari jawaban atas masalah yang dihadapi dan berusaha memeriksa, mencari dan menyimpulkan sendiri secara logis, kritis, analitis dan sistematis. Cara ini akan 
mendorong siswa untuk meningkatkan penalaran dan berpikir secara bebas, terbuka dengan senang hati maka akan memperdalam pengetahuannya secara mandiri.

Berdasarkan data di SMP Islam Terpadu Askhabul Kahfi yang didapat melalui wawancara dan observasi dengan guru matematika dan siswa didapat bahwa dari sekian materi pembelajaran matematika, materi aritmatika sosial termasuk materi yang sulit. Hal ini terlihat dari hasil statistika Ujian Nasional di SMP Islam Terpadu Askhabul Kahfi yang tercatat tingkat kesalahan terbanyak berada pada materi tersebut, yang berarti siswa kurang memahami konsep materi tersebut. Siswa mudah mengerjakan soal-soal hitungan, akan tetapi kesulitan untuk memahami konsep materi tersebut, umumnya siswa hanya menghafalkan rumus-rumus yang sudah diajarkan. Oleh karena itu perlu adanya tindakan perbaikan untuk mempermudah siswa dalam memahami konsep-konsep tersebut dengan cara melatih siswa untuk memiliki pemahaman konsep untuk memahami konsep-konsep dalam matematika.

Sunadi (2014) berpendapat bahwa bila siswa belajar Matematika terpisah dari pengalaman Mereka sehari-hari maka akan cepat lupa dan tidak dapat mengaplikasikan matematika sehingga berdasarkan pendapat di atas, pembelajaran matematika di kelas ditekankan pada keterkaitan antara konsep-konsep matematika dengan pengalaman anak sehari-hari. Selain itu, perlu menerapkan kembali konsep matematika yang telah dimiliki anak pada kehidupan sehari-hari atau pada bidang lain sangat penting dilakukan. Salah satu metode pembelajaran matematika yang berorientasi pada matematisasi pengalaman sehari-hari (mathematize of everyday experience) dan menerapkan matematika dalam kehidupan sehari-hari adalah RME. Pembelajaran matematika pada dasarnya mengasah cara berpikir logis siswa melalui peningkatan kemampuan komunikasi matematika siswa. Maka, pembelajaran RME dirasa sangat cocok untuk meningkatkan kemampuan komunikasi matematika siswa.

Proses pembelajaran aritmatika sosial berpendekatan RME, perlu terlebih dahulu disiapkan perangkat pembelajaran teori aritmatika sosial yang berpendekatan RME yang saat ini belum ada yang terpublikasi secara luas. Oleh karena itu perlu dikembangkan model pembelajaran materi aritmatika sosial berpendekatan RME berbasis soal open-ended untuk digunakan dalam upaya meningkatkan kemampuan pemahaman dan komunikasi matematika siswa SMP. Selain meningkatkan pemahaman konsep matematika, pembelajaran berbasis masalah mampu menghasilkan berpikir 
kreatif, mengambil keputusan yang kritis, dan menyelesaiakan masalah dengan tepat (Padmavathy \& Mareesh, 2013). Pengembangan model pembelajaran yang baik diawali pengembangan perangkat pembelajaran yang berkualitas. Perangkat pembelajaran yang akan dikembangkan meliputi bahan ajar siswa berupa kumpulan silabus, rencana pelaksanaan pembelajaran, dan lembar kerja siswa. Penelitian akan dilaksanakan berkaitan dengan pengembangan perangkat pembelajaran matematika materi aritmatika sosial. Pentingnya penelitian pengembangan dikemukakan oleh Jong (2005) yang mengatakan bahwa penelitian pengembangan diperlukan untuk meningkatkan kolaborasi antara peneliti dan para guru. Lebih lanjut Jong menyarankan suatu metode penelitian dengan yang disebut pengembangan dengan melibatkan tahapan-tahapan siklus yang diulang melalui serangkaian uji coba dan revisi.

Melalui penelitian ini diharapakan pengajaran materi aritmatika sosial kelas VIII dapat mencapai pengembangan indikator kompetensi inti dan kompetensi dasar yang telah ditetapkan dan meningkatkan kemampuan komunikasi matematika siswa. Pada akhirnya diharapkan dapat meningkatkan hasil belajar siswa terhadap materi matematika. Penelitian ini merupakan penelitian pengembangan pembelajaran matematika dengan pendekatan RME berbasis soal open-ended yang difokuskan untuk meningkatkan kemampuan komunikasi matematika siswa pada materi aritmatika sosial.

\section{METODE PENELITIAN}

Bentuk penelitian yang digunakan dalam penelitian ini adalah Research and Development ( $\mathrm{R} \& \mathrm{D})$. Pada penelitian ini mengacu pada model pengembangan pendidikan Plomp, yaitu sebuah model yang terbagi menjadi 5 tahap. Tahap-tahap tersebut adalah (1) tahap investigasi awal, (2) tahap perancangan, (3) tahap realisasi/konstruksi, (4) tahap tes, evaluasi, dan revisi, dan (5) tahap implementasi (Hobri, 2009). Subjek dalam penelitian ini adalah siswa kelas VIII SMP Islam Terpadu Askhabul Kahfi Tahun Pelajaran 2017/ 2018 yang terdiri dari 4 kelas dengan 130 siswa. Desain implentasi menggunakan Posttest Only Control-Group Design (Creswell, 2009: 161). Instrumen pada penelitian ini meliputi: (1) instrumen penilaian/ uji ahli dan siswa terhadap produk yang dikembangkan; (2) instrumen soal tes kemampuan komunikasi matematika materi aritmatika social; dan (3) instrumen lembar observasi penanaman sikap positif siswa. 
Teknik yang digunakan dalam penelitian ini adalah teknik pengukuran berupa kelayakan perangkat pembelajaran, tes kemampuan komunikasi matematika dan sikap positif siswa. Indikator komunikasi matematika yang digunakan adalah; (1) Menggunakan kemampuan memberi gagasan (diketahui dan ditanyakan) suatu ide matematika (2) Menjelaskan ide dan relasi matematika dengan gambar (3) Menggunakan notasi dan struktur matematik untuk menyajikan ide menggambarkan hubungan pembuatan model (4) Menyatakan gambar ke dalam model matematika (5) Mengapresiasi nilai-nilai dari suatu notasi matematis termasuk aturan-aturannya dalam mengembangkan ide matematika. Analisis yang digunakan berupa analisis hasil validasi ahli dan uji keefektifan. Hasil post test pada kelas yang dilakukan tindakan dibandingkan dengan kelas yang tidak dilakukan tindakan dan untuk memastikannya dilakukan dengan (1) Uji Ketuntasan, (2) Uji Beda, dan (3) Uji Regresi Linier Sederhana.

Uji ketuntasan data nilai kemampuan komunikasi kelas yang menggunakan penerapan perangkat pembelajaran matematika dengan pendekatan RME berbasis soal open-ended menggunakan rumusan sebagai berikut. (1) Rata-rata nilai kemampuan komunikasi kelas yang menggunakan penerapan perangkat pembelajaran matematika dengan pendekatan RME berbasis soal open-ended lebih besar dari 70; (2) Ketuntasan klasikal kelas yang menggunakan penerapan perangkat pembelajaran matematika dengan pendekatan RME berbasis soal open-ended lebih besar dari 75\%); (3). rerata kelas yang menggunakan penerapan perangkat pembelajaran matematika dengan pendekatan RME berbasis soal open-ended lebih besar dari kelas yang tidak menggunakan penerapan perangkat pembelajaran matematika dengan pendekatan RME berbasis soal open-ended; (4) Ada pengaruh sikap positif siswa terhadap kemampuan komunikasi matematika siswa.

\section{HASIL DAN PEMBAHASAN}

Perangkat Pembelajaran (buku ajar) Aritmatika Sosial dan Perbandingan yang sudah disusun, dilakukan uji validasi oleh beberapa ahli. Ada 3 ahli yang menilai, yaitu 2 validator ahli materi dan 1 validator ahli media. Rekapitulasi hasil validasi disajikan pada Tabel 1.

Tabel 1. Hasil Validasi Ahli Terhadap Buku ajar

\begin{tabular}{ccc}
\hline Validator & Skor & Kriteria \\
\hline Validator Materi 1 & 141 & Layak \\
\hline Validator Materi 2 & 170 & Sangat Layak \\
\hline Validator Media & 107 & Sangat Layak \\
\hline
\end{tabular}


Berdasarkan Tabel 1 dapat dilihat bahwa buku ajar yang dikembangkan sudah layak diterapkan pada proses pembelajaran. Saran dari penilai atau ahli mengenai buku ajar yang dikembangkan, pada dasarnya sudah memenuhi kriteria penulisan atau penyusunan buku ajar yang baik. Permasalahan masih terdapat kesalahan mendasar, seperti kesalahan penggunaan istilah meskipun memiliki makna yang beda, penggunaan kata atau pemilihan kata dalam sebuah konteks kalimat menjadi kesalahan yang wajar dan sering dilakukan oleh penulis buku ajar lainnya. Desain yang disajikan pada buku ajar harapannya merupakan hasil kreatifitas sendiri.

Setelah buku ajar dinyatakan layak untuk digunakan, kemudian diimplementasikan pada proses pembelajaran kelas VIII. Implementasi dilakukan untuk mengetahui keefektifan buku terhadap kemampuan komunikasi matematika siswa berdasarkan nilai postes. Adapun rekapitulasi data hasil tes evaluasi komunikasi disajikan pada Tabel 2.

Tabel 2. Rekapitulasi Hasil Nilai Kemampuan Komunikasi

\begin{tabular}{ccccc}
\hline Kelas & Jumlah Siswa & $\begin{array}{c}\text { Jumlah Siswa } \\
\text { Tuntas }\end{array}$ & $\begin{array}{c}\text { Jumlah Siswa } \\
\text { Tidak Tuntas }\end{array}$ & Rerata \\
\hline $\begin{array}{c}\text { Penerapan } \\
\text { Pembelajaran RME }\end{array}$ & 64 & 47 & 17 & 73,43 \\
\hline $\begin{array}{c}\text { Tanpa Penerapan } \\
\text { Pembelajaran RME }\end{array}$ & 66 & 15 & 51 & 64,56 \\
\hline
\end{tabular}

Selain menguji perbedaan kemampuan komunikasi siswa pada kelas eksperimen dan kelas kontrol, juga dilakukan observasi terhadap sikap positif siswa pada kelas eksperimen setiap pertemuannya. Data observasi tersebut digunakan untuk melihat sejauh mana buku ajar yang dikembangkan mampu membantu penerapan sikap positif pada siswa. Observasi terhadap sikap siswa dilakukan menggunakan metode peer assesment, dimana 1 siswa dinilai oleh 2 siswa yang lain. Hal ini bertujuan untuk memudahkan penulis mengetahui sikapnya dan menjaga objektivitas penilaian selama pembelajaran. Hasil observasi sikap positif siswa sebagaimana selama 6 pertemuan terdapat; $8 \%$ siswa dalam kategori cukup, $90 \%$ siswa dalam kategori baik, dan $2 \%$ dalam kategori sangat baik.

\section{Uji Ketuntasan}

Rerata nilai kelas yang menggunakan penerapan perangkat pembelajaran matematika dengan pendekatan RME berbasis soal open-ended sebesar 73,43 ( $\mu>70)$ 
hal tersebut dapat dilihat pada tabel 2, sehingga dapat disimpulkan bahwa perangkat pembelajaran matematika dengan pendekatan RME berbasis soal open-ended berpengaruh positif (efektif) terhadap kemampuan komunikasi matematika siswa. Berdasarkan Tabel 2 bahwa siswa yang tuntas pada kelas yang menggunakan penerapan perangkat pembelajaran matematika dengan pendekatan RME berbasis soal open-ended sebanyak 47 siswa, yang artinya ketuntasan klasikal kelas yang menggunakan penerapan perangkat pembelajaran matematika dengan pendekatan RME berbasis soal open-ended sebesar 76,6\%. Karena ketuntasan klasikal lebih besar dari 75\% ( $\pi>75 \%)$, maka dapat disimpulkan bahwa perangkat pembelajaran matematika dengan pendekatan RME berbasis soal open-ended berpengaruh positif (efektif) terhadap kemampuan komunikasi matematika siswa. Dan didapatkan pula bahwa Rerata kelas yang menggunakan penerapan perangkat pembelajaran matematika dengan pendekatan RME berbasis soal open-ended sebesar 73,43, sedangkan rerata kelas yang tidak menggunakan perangkat pembelajaran matematika dengan pendekatan RME berbasis soal open-ended sebesar 64,56. Karena $\mu_{1}>\mu_{2}$, maka $\mathrm{H}_{0}$ ditolak dan dapat disimpulkan bahwa perangkat pembelajaran matematika dengan pendekatan RME berbasis soal open-ended berpengaruh positif (efektif) terhadap kemampuan komunikasi matematika siswa.

Uji regresi digunakan untuk menunjukkan pengaruh sikap positif siswa terhadap kemampuan komunikasi siswa. Uji regresi linier sederhana ini menggunakan bantuan SPSS 17 for windows. Adapun hasil uji regresi linier disajikan pada Tabel 4.

Tabel 4. Uji Regresi Linier Sederhana

\begin{tabular}{|c|c|c|c|c|c|c|}
\hline \multicolumn{7}{|c|}{ Coefficients $^{\mathrm{a}}$} \\
\hline & & Unstandardized C & efficients & $\begin{array}{l}\text { Standardized } \\
\text { Coefficients }\end{array}$ & & \\
\hline \multicolumn{2}{|l|}{ Model } & B & Std. Error & Beta & $\mathrm{T}$ & Sig. \\
\hline \multirow[t]{2}{*}{1} & (Constant) & 53.052 & 10.197 & & 5.203 & .000 \\
\hline & Sikap_Positif & .507 & .252 & .248 & 2.012 & .049 \\
\hline
\end{tabular}

a. Dependent Variable: Kemampuan_Komunikasi

Sebelum melakukan pengujian hipotesis dalam penelitian terlebih dahulu dilakukan analisis regresi linier sederhana untuk mengetahui hubungan fungsional. Persamaan regresinya yaitu $\hat{Y}=53,052+0,507 x$. Berdasarkan persamaan tersebut koefisien regresi dari masing-masing variabel independen bernilai positif, artinya sikap 
positif siswa berpengaruh positif terhadap kemampuan komunikasi matematika siswa. Nilai 53,052, yang berarti jika sikap positif siswa sama dengan nol (tidak ada perubahan), maka kemampuan komunikasi matematika siswa akan sama dengan 53,052. Nilai 0,507, yang berarti jika sikap positif siswa sama dengan satu, maka kemampuan komunikasi matematika siswa akan sama dengan 0,507. Berdasarkan Tabel 4 terlihat bahwa $t_{\text {hitung }}=2,012$. Karena $t_{\text {hitung }}>t_{\text {tabel }}(1,99834)$, maka $\mathrm{H}_{0}$ ditolak. Sehingga dapat disimpulkan bahwa sikap positif siswa berpengaruh positif terhadap kemampuan komunikasi matematika siswa.

Selama penggunaan buku ajar, siswa berlatih menyelesaikan masalah kontekstual pada materi Aritmetika Sosial dan Perbandingan. Masalah-masalah yang disajikan berkaitan dengan konteks yang mudah dijumpai siswa dalam kehidupan sehari-hari. Penggunaan buku ajar melalui pembelajaran dengan pendekatan RME memudahkan siswa dalam menemukan konsep matematika yang termuat pada setiap masalah yang disajikan dalam buku ajar. Secara tidak langsung, siswa telah berlatih dalam meningkatkan kemampuan komunikasi matematika. Sehingga keberadaan buku ajar atau buku teks sangat penting karena berdampak pada pencapaian siswa pada tes evaluasi kemampuan komunikasi matematika yang dilakukan siswa di akhir tahap implementasi (implementatio) hal tersebut sesuai pendapat Cahyono dan Adilah, (2016) menyatakan keberadaan buku teks sangat penting karena buku teks merupakan salah satu perangkat dasar dalam proses pembelajaran. Hasil postes literasi matematika menunjukkan bahwa siswa rata-rata telah mencapai kemampuan komunikasi matematika dengan nilai rata-rata 73,42. Hasil tersebut menunjukkan bahwa buku ajar efektif digunakan dalam memfasilitasi pencapaian kemampuan komunikasi matematika siswa.

Efektivitas buku ajar tersebut sangat ditentukan oleh kegiatan pembelajaran yang baik dan penggunaan buku ajar yang tepat. Kemampuan guru matematika dalam mengatur kegiatan pembelajaran menjadi kunci keberhasilan siswa memanfaatkan buku ajar sehingga berpengaruh terhadap pencapaian siswa pada evaluasi kemampuan komunikasi matematika. Selain itu, guru memiliki pengetahuan dan keterampilan tentang matematika dan RME serta dapat menerapkannya dalam pembelajaran matematika. Guru mampu memfasilitasi siswa dalam berpikir, berdiskusi, dan bernegoisasi. Selama pembelajaran, guru mendampingi dan mendorong siswa agar berani mengungkapkan gagasan dan menemukan strategi pemecahan masalah menurut mereka sendiri. Guru juga mampu mengelola kelas sedemikian sehingga mendorong siswa bekerja sama dan berdiskusi dalam rangka pengonstruksian pengetahuan siswa. Di setiap akhir pembelajaran, guru mengajak siswa menyarikan (summarize) fakta, konsep, dan prinsip matematika yang telah dipelajari melalui proses refleksi dan konfirmasi. Kemampuan guru tersebut menjadikan proses pembelajaran dengan 
pendekatan RME berjalan dengan baik dan penggunaan buku ajar menjadi lebih efektif dan tepat tujuan.

Buku ajar yang dikembangkan, selain mengajarkan kemampuan komunikasi matematika siswa dalam menyelesaikan suatu masalah, namun juga memuat nilai-nilai sikap positif diantaranya percaya diri, berani, kritis. Harapannya adalah bahan ajar yang dikembangkan ini mampu membantu penerapan sikap pada proses pembelajaran. Sehingga siswa sudah dibiasakan dengan sikap-sikap yang memang dibutuhkan. Sikap positif siswa dapat dilihat pada sikap siswa selama pembelajaran (Aini, et al, 2015). Terkait penyajian materi pada bahan ajar harus memuat nilai kebaikan dan ketauladanan. Komposisi pengetahuan yang disampaikan seimbang dengan nilai sikap yang dibutuhkan. Penerapan buku ajar ini selama pembelajaran, juga menilai sikap siswa dengan cara peer assesment. Melalui metode ini diharapkan mendapatkan hasil yang objektif, dimana 1 siswa hanya mengamati 2 siswa. Sehingga fokus objek yang diamati tidak terlalu banyak (White, 2009). Namun pada awal pembelajaran siswa sudah diberikan petunjuk tentang penilaian pada hal ini. Berdasarkan observasi yang sudah dilakukan, terlihat adanya peningkatan sikap siswa di setiap pertemuannya. Peningkatan sikap siswa ini dihasilkan oleh penggunaan buku ajar yang sudah dikembangkan. Hal ini sesuai dengan yang disampaikan guru pada studi pendahuluan, bahwa nilai sikap positif dapat disajikan melalui teks bacaan yang disertai gambar kehidupan sosial dan kegiatan pembelajaran.

Secara umum, sikap positif siswa di SMP Askhabul Kahfi sudah baik. Hal ini disebabkan lingkungan sekitar yang mendukung pada pendidikan. Salah satu penyebabnya adalah banyak yang bertempat tinggal di sekitar pondok pesantren. Sehingga sikap mereka termbimbing dengan baik. Namun yang masih perlu diperhatikan adalah nilai rasa ingin tahu dan gemar membaca siswa yang masih kurang. Berdasarkan hasil observasi yang diperoleh, siswa masih kurang dalam mencari informasi di luar secara mandiri. Siswa hanya mengandalkan informasi yang disampaikan oleh guru di sekolah. Siswa belum percaya diri pada kemampuan yang dimiliki, sehingga siswa perlu ditanamkan dan dipupuk oleh guru agar siswa dapat lebih bangga terhadap potensi yang dimilikinya. 


\section{SIMPULAN}

Berdasarkan hasil penelitian dan pembahasan, diperoleh simpulan bahwa (1) Perangkat pembelajaran aritmetika dengan pendekatan RME yang dikembangkan valid digunakan berdasarkan dari penilaian pakar ahli. Dan sesuai hasil uji coba kelas kecil dan kelas besar, dan (2) Perangkat pembelajaran aritmetika dengan pendekatan RME yang dikembangkan efektif. Hal ini ditunjukkan dengan (a) rerata nilai evaluasi kemampuan komunikasi kelas yang menggunakan perangkat pembelajaran matematika 73, $42(\mu>70)$ dan ketuntasan klasikal sebesar 76,6\% ( $\pi>75 \%)$; (b) rerata rerata kelas yang menggunakan penerapan perangkat pembelajaran matematika dengan pendekatan RME berbasis soal open-ended $(73,42)$ lebih besar dari kelas yang tidak menggunakan penerapan perangkat pembelajaran matematika dengan pendekatan RME berbasis soal open-ended $(64,57)$, serta (c) dari uji regresi diperoleh $t_{\text {hitung }}=2,012, t_{\text {hitung }}(2,012)>$ $t_{\text {tabel }}(1,99834)$. 


\section{DAFTAR PUSTAKA}

Aini, NN., Sukestiyarno \& Waluya, SB. 2015. Analisis Komunikasi Matematis Dan Tanggung Jawab Pada Pembelajaran Formulate Share Listen Create Materi Segiempat. Unnes Journal of Mathematics Education Research. 4 (2).

Cahyono, B., \& Adilah, N. (2016). Analisis Soal Dalam Buku Siswa Matematika Kurikulum 2013 Kelas Viii Semester I Berdasarkan Dimensi Kognitif Dari Timss. Jrpm, 1 (1), 86-98. Retrieved from http://jrpm.uinsby.ac.id

Creswell, J. 2009. Research Desaign; Qualitative, Quantitative, and Mix Methods Approaches. California: SAGA.

Dickinson, P., Eade, F. \& Hough, S.. 2010. "Using Realistic Mathematics Education with Low to Middle Attaining Pupils in Secondary Schools". Proceedings of the British Congress for Mathematics Education. 5 (1).

Dickinson, P. \& Hough, S.. 2012. Using Realistic Mathematic Education in UK Classrooms. UK: Penny. ISBN: 978-0-948186-24-0

Fauzan, A. 2002. Applying Realistic Mathematics Education (RME) in Teaching Geometry In Indonesian Primary Schools. ISBN 90-365-18-43-1.

. 2011. "Pendidikan Matematika Realistik: Suatu Tantangan dan Harapan". Jurnal Matematka USD. 3 (2).

Hobri. 2009. Metode Penelitian Pengembangan (Aplikasi Pada Penelitian Pendidikan Matematika). Jember: FKIP Universitas Jember Press.

Jong, O. 2005. "Research and Teaching Practice in Mathematics Education: Living Apart or Together?". Mathematics Education International. 6 (1).

Marpaung, Y. 2001. "Prospek RME Untuk Pembelajaran Matematika Di Indonesia". Makalah, disampaikan pada Seminar Nasional tentang Realistic Mathematic Education Universitas Negeri Surabaya.

Padmavathy, R.D. \& Mareesh, K.. 2013. "Effectiveness of Problem Based Learning In Mathematics". International Multidisciplinary e-Journal. 2 (1).

Priyatno, D. 2009. Belajar Olah Data Dengan SPSS. Yogyakarta: Andi.

Soedjadi, R. 2000. Kita Pendidikan Matematika di Indonesia (Konstatasi Keadaan Masa Kini Menuju Harapan Masa Depan). Jakarta: Direktorat Jenderal Pendidikan Tinggi, Departemen Pendidikan Nasional.

Sunadi. 2014. "Pembelajaran Matematik Realistik Untuk Meningkatkan Kemampuan Komunikasi Matematik Siswa". Prosiding Seminar Nasional Pendidikan Matematika ProgramPasca Sarjana STKIP Siliwangi Bandung. (1).

White, Eddy. 2009. "Student Perspectives of Peer Assessment for Learning in a Public Speaking Course". Asian EFL Journal. 1 (1). 